\title{
Integrating heterogeneity across spatial scales: interactions between Atrina zelandica and benthic macrofauna
}

\author{
J. E. Hewitt ${ }^{1, *}$, S. F. Thrush ${ }^{1}$, P. Legendre ${ }^{2}$, V. J. Cummings ${ }^{1}$, A. Norkko ${ }^{1}$ \\ ${ }^{1}$ National Institute of Water and Atmospheric Research, PO Box 11-115, Hamilton, New Zealand \\ ${ }^{2}$ Département de sciences biologiques, Université de Montréal, C.P. 6128, succ. Centre-ville, Montréal, Québec H3C 3J7, Canada
}

\begin{abstract}
Techniques are needed to extend the generality of detailed experimental field studies. Multi-resolution sampling designs nest fine-scale sampling within information about broad-scale processes that may affect finer-scale data. These designs are very appropriate for studies seeking to detect the effects of processes operating over a variety of scales. We tested the utility of a novel, lowintensity/cost, multi-resolution sampling design in an investigation of the relationship between the suspension-feeding pinnid bivalve Atrina zelandica and surrounding benthic macrofauna. Interactions were modelled at different spatial scales, and a variety of covariates were included in the search for the best statistical and most sensible ecological model. We chose our sampling sites to encompass broad-scale gradients in A. zelandica density and size, depth, sediment characteristics and hydrodynamics. We found these gradients helped explain the relationship between $A$. zelandica and associated benthic macrofauna. Our results suggest that the strength of effects of $A$. zelandica on benthic macrofauna was dependent on 2 aspects of spatial scale: grain (the area over which A. zelandica measurements were made) and lag (the distance between where the A. zelandica and the macrofauna were sampled). By nesting fine-scale measures of benthic macrofaunal community composition within different spatial arrangements of individual A. zelandica, we were able to determine that the maximum distance between individual $A$. zelandica, rather than density estimates, better explained effects of $A$. zelandica on benthic macrofauna. This suggests the value of integrating broad-scale surveys with localised experiments so that organism interactions can be more generally interpreted on the basis of dynamics within landscapes rather than as density-to-density comparisons.
\end{abstract}

KEY WORDS: Multi-resolution sampling designs $\cdot$ Nested sampling $\cdot$ Physical gradients $\cdot$ Spatial scale $\cdot$ Interspecific interactions $\cdot$ Suspension feeders $\cdot$ Benthic macrofauna $\cdot$ Landscape phenomena Surveys · Atrina zelandica

\section{INTRODUCTION}

Understanding mechanisms that drive species interactions is a key problem in population and community ecology. Manipulative field experiments are generally considered the best way of testing suspected mechanistic interactions; however, these are invariably conducted over limited space- and timescales. The implication of work reporting that spatial and temporal

*E-mail: j.hewitt@niwa.cri.nz aspects of sampling designs affect our understanding of ecological processes (e.g. Wiens 1986, Thrush 1991, Dayton 1994, Horne \& Schneider 1994, Whitlatch et al. 1998) is concern about the extrapolation of results of field experiments in space and time (Dayton et al. 1999, Thrush et al. 2000). Thus, the explicit incorporation of scale into ecological studies becomes imperative if we are to understand the importance of potential changes in processes at different scales and the limitations of specific sampling designs (e.g. Dayton \& Tegner 1984, Wiens et al. 1993, Giller et al. 1994, Schnei- 
der 1994, Hewitt et al. 1997, Bellehumeur \& Legendre 1998, Thrush et al. 1999). One potentially useful empirical approach is to develop low-cost rapid assessment techniques that can be used in a variety of locations to assess the generality of mechanisms identified by field experiments. Multi-resolution nested sampling designs can overcome problems of interpreting relationships influenced by a number of processes operating on different spatial and temporal scales (Fortin et al. 1989, King 1991, Bell et al. 1995, Thrush et al. 1997, Hewitt et al. 1998, Bergin et al. 2000). Such designs also allow rapid assessment of the relationships amongst community members and environmental characteristics. In this paper we describe a rapid-assessment survey technique and investigate the usefulness of multi-scale statistical modelling to test hypotheses about interspecific interactions, by exploring the relationship between the pinnid bivalve Atrina zelandica (Gray) and surrounding benthic macrofauna. This technique is used to provide information over a broader range of conditions than available from feasible experiments (Cummings et al. 2001).

Multi-resolution sampling designs nest fine-scale information within information about broad-scale processes that may interact with the fine-scale detail usually studied by manipulative field experiments (e.g. Moody \& Woodcock 1995, Azovsky et al. 2000). Large areas (i.e. extents) sampled contiguously with coarse resolution techniques (e.g. aerial photographs, sidescan sonar) can be used to identify heterogeneity at that scale and subregions for finer-resolution sampling. This process of nesting techniques that sample at different resolutions ideally allows 1 sampling resolution to determine appropriate extents, inter-sample distances (i.e. lags) and number of samples needed to incorporate within-site variability for the next (finer) resolution. Such designs may be used for rapid assessment of communities and environmental characteristics. Further, by requiring studies to focus explicitly on lag, extent and grain (i.e. smallest sample unit; see Legendre \& Legendre 1998 for full definitions), these designs can provide insights into how processes are perceived to change with scale (Schneider et al. 1997, McIntyre \& Wiens 2000). In a survey design, although point hypothesis testing of causal relationships is not possible, relationships can be investigated by working along gradients, including a variety of covariates and searching for the best statistical model (which is also ecologically sensible). Thus, multi-scale statistical modelling may provide us with an ability to tease apart heterogeneity and interpret relationships resulting from processes operating over a variety of scales and also increase generality of results.

The multi-resolution sampling design is affected by how cryptic the organisms studied are. We have previ- ously described a sampling design for cryptic infaunal macrofauna (Hewitt et al. 1997). However, where a potentially important organism is visible (whether by eyesight or remote devices), designs that incorporate knowledge of landscape characteristics of the visible organism are possible. Such designs may increase the knowledge gained from the study. In this paper we investigate the usefulness of a new sampling design and multi-scale statistical modelling in a semi-cryptic system, by exploring the relationship between the pinnid bivalve Atrina zelandica and surrounding benthic macrofauna. A. zelandica is a long-lived, large suspension-feeder which grows up to $30 \mathrm{~cm}$ long and $12 \mathrm{~cm}$ wide and protrudes $1 / 3$ to $2 / 3$ of its length above the sediment surface. The landscapes produced by A. zelandica vary from dense carpets to patches of varying sizes and densities, or a single $A$. zelandica surrounded by large areas of bare sediment. Patches are generally a single age of $A$. zelandica exhibiting differential growth and survival.

The effect of Atrina zelandica on the local distribution of benthic macrofauna (dominated by animals with annual recruitment) reported by a small field survey (Warwick et al. 1997, Cummings et al. 1998) and a large manipulative field experiment (Cummings et al. 2001) was dependent on time, environment and ambient communities. The reported variability suggested that answering the following questions would allow us to extend our knowledge of how the benthic community interacted with $A$. zelandica. Firstly, what was the scale at which $A$. zelandica had the strongest effect on benthic macrofaunal communities? This is important, as an earlier experiment with another suspension feeding bivalve Austrovenus stutchburyi (Whitlatch et al. 1997) showed that experimental results were dependent on the size of experimental plots (i.e. grain). Secondly, was the effect of $A$. zelandica on benthic macrofauna driven by A. zelandica density alone, or was it dependent on how individual A. zelandica were arranged within patches? Thirdly, how did broad-scale gradients in depth, sediment characteristics and flow affect relationships between the small-scale spatial arrangement of individual A. zelandica and the local benthic macrofaunal community?

While all these questions are specific to the Atrina zelandica-benthic macrofaunal community relationship, they can be generalised to the following broad questions: How can we determine the scales at which interspecific interactions are greatest? Is the spatial distribution of a species important in influencing interspecific interactions? What part do broad-scale physical variables play in mediating interspecifc interactions? All of these are important to our understanding of how interspecific interactions work across spatial scales and what factors are likely to mediate the interaction process. 


\section{MATERIALS AND METHODS}

Atrina-dominated communities. Atrina zelandica are common in the subtidal sandy and muddy softsediments of NE New Zealand and often form large patches (up to $100 \mathrm{~m}^{2}$ ) on the seafloor. A. zelandica modify boundary flow conditions in tidally driven systems (Green et al. 1998), potentially increasing water turbulence and sediment resuspension at low densities and preventing settlement from the water column to the bed, by inducing 'skimming' flow, at high densities. Further modification of the local habitat by $A$. zelandica results from the production of biodeposits (pseudofaeces in particular) that modify sediment deposition and organic loading (Norkko et al. 2001). A. zelandica, as other suspension feeders, also have the potential to influence recruitment of benthos (Woodin 1976) but this can be influenced by boundary-layer hydrodynamics (Ertman \& Jumars 1988, Andre et al. 1993) and type of colonists (Commito 1987, Commito \& Boncavage 1989). Furthermore, in soft-sediment marine systems, animals that protrude above the sediment surface can be expected to provide refuge from predation and substrates for epifaunal settlement (e.g. Crowder \& Cooper 1982, Luckenbach 1984, Lee \& Kneib 1994). Given these characteristics, we expect these bivalves to act as a foundation species (sensu Dayton 1972) or as ecosystem engineers (Jones et al.

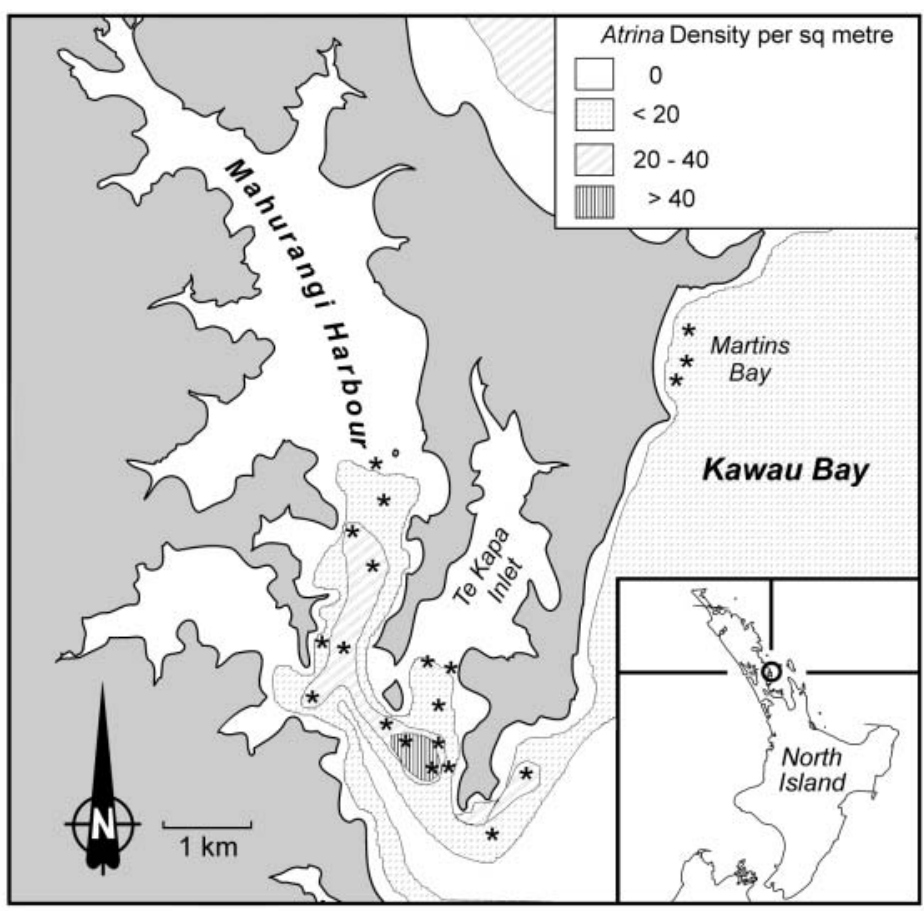

Fig. 1. Location of sites relative to broad-scale variations in Atrina zelandica density
1994, Lawton \& Jones 1995) with detectable effects on the surrounding community. A companion manipulative field experiment has demonstrated that densities of 75 A. zelandica $\mathrm{m}^{-2}$ in $4 \mathrm{~m}^{2}$ patches significantly influences benthic community structure, but that the effect varies depending on location and time of sampling (Cummings et al. 2001).

Study sites. This survey was carried out in and around Mahurangi Harbour, a small harbour $\left(25 \mathrm{~km}^{2}\right)$ on the east coast of the North Island of New Zealand, approximately $50 \mathrm{~km}$ north of Auckland (Fig. 1). Fifteen sites were located within the lower harbour (where the mean depth varied from 3 to $9.5 \mathrm{~m}$ ) and 5 sites were located in sandy areas outside the harbour within Kawau Bay (where mean depth varied from 6 to $7.5 \mathrm{~m}$ ). Data were collected over a single week of spring tides (tidal range $3.1 \mathrm{~m}$ ), in January 1997. Circulation within the harbour is dominated by semi-diurnal tides and the water column is typically well-mixed. Tidal streams in the lower harbour attain maximum speeds of $\sim 50 \mathrm{~cm} \mathrm{~s}^{-1}$ at $100 \mathrm{~cm}$ above the bed, while outside the harbour wave-induced orbital flows dominate. Large beds of Atrina zelandica are dominant features both outside and inside the harbour, although the size and spatial arrangement of the A. zelandica within the beds and the spatial extent of the beds vary.

Prevous side-scan-sonar surveys and diver observations in Mahurangi Harbour were used to locate Atrina zelandica patches (Fig. 1). Sites spanning the greatest possible range of variability in spatial extent of beds and in the spatial arrangement of $A$. zelandica within them were chosen. Sites without $A$. zelandica were also included. Each site was centred in an area of relatively homogeneous seabed that stretched for at least $100 \mathrm{~m}$ in a direction parallel to the principal tidal axis.

Video observations were made at each site along a haphazardly located pair of $20 \mathrm{~m}$ long transects. One transect from each pair was aligned with the principal axis of the tidal flow or wave-induced sediment ripples and the other was located at right angles to this (Fig. 2a). This method was used in case Atrina zelandica aligned themselves relative to water movement. The video camera was held vertically at constant elevation above the bed by a diver. To sample the benthic macrofauna, cores (10 $\mathrm{cm}$ diam. and $10 \mathrm{~cm}$ deep) were taken along each transect in positions that represented the extreme variability of $A$. zelandica distributions observed along that transect by the diver (Fig. 2a). The number of cores collected from a site varied from 3 to 10 depending on the diverobserved heterogeneity of the A. zelandica dis- 


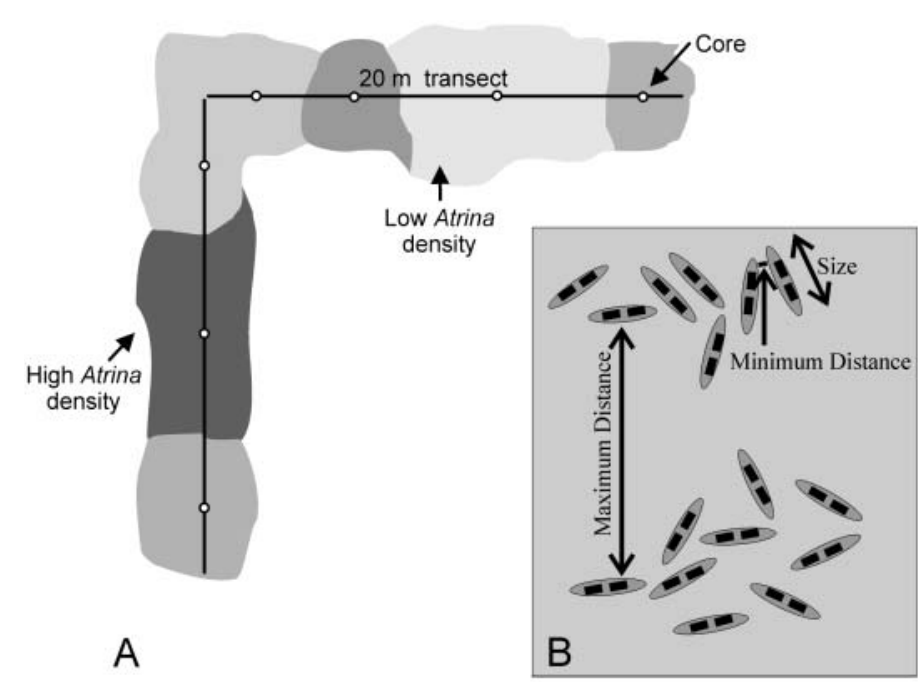

Fig. 2. Atrina zelandica. Diagrammatic representations of: (a) the macrofaunal sampling design (cores were taken along the ' $\mathrm{L}$ '-shaped transect in positions that represented the extreme variability of distributions along that transect); and (b) aspects of the spatial arrangement measured

tribution at that site, with more cores collected in more heterogeneous sites. This design allowed us to maximize the range of conditions sampled within each site with minimal sampling effort, and thus increase the number of sites sampled. The location of each core sample along the transect was recorded.

At each site, a $2 \mathrm{~cm}$ deep scoop of surface sediment was collected for later analysis of particle size and amount of organic carbon. Latitude and longitude of the sites was determined by GPS (error $\pm 10 \mathrm{~m} 95 \%$ of the time).

Benthic macrofauna, Atrina zelandica and environmental measurements. Macrofaunal cores were sieved on a $500 \mu \mathrm{m}$ mesh and preserved in $70 \%$ isopropyl alcohol. Macrofauna in each core were identified to the lowest taxonomic level practical and counted. As the dominant taxa varied between sites, total numbers within some aggregate groups were calculated (i.e. numbers of deposit feeders, suspension feeders and predators/scavengers, numbers of organisms living on and near the sediment surface [i.e. $<2 \mathrm{~cm}$ deep], numbers of mobile organisms and total numbers of individuals and taxa).

Using a marked transect rope for a scale, each videoed transect was divided into $50 \times 40 \mathrm{~cm}$ quadrats (40 $\mathrm{cm}$ was the maximum width that we could observe at all sites). A frame-grabber was then used to generate a digital image of each quadrat from the video footage. Each digital image was examined for the presence of Atrina zelandica, and the following parameters measured for use as variables of spatial arrangement of A. zelandica: A. zelandica shell width (size), total den-

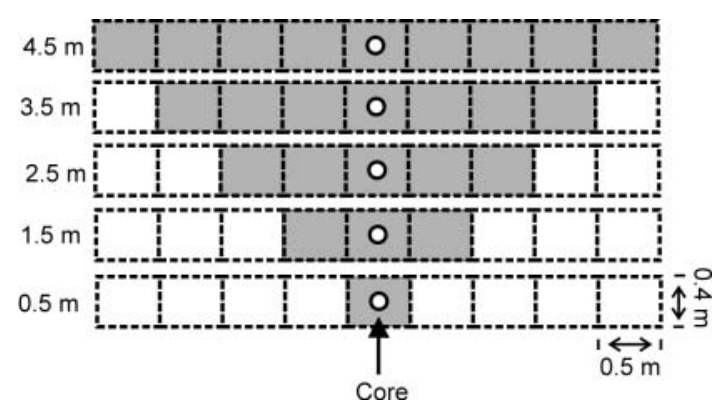

Fig. 3. Atrina zelandica. Diagrammatic representations of the grains over which the spatial arrangement were measured. Quadrats compared with the macrofaunal core, for each grain or lag, are shaded

sity of $A$. zelandica, minimum nearest-neighbour distance between $A$. zelandica and maximum clear distance between individual $A$. zelandica (Fig. 2b). The distance from the core to the nearest $A$. zelandica was also measured. Size of patches of $A$. zelandica was not measured due to difficulties in defining patches (see also Azovsky et al. 2000). Three sites could not be digitized successfully due to low visibility, sinking of the rope into the extremely soft muds or drifting seaweed. However, none of these sites had any A. zelandica, so they could still be included in the analysis.

In order to investigate the effect of different resolutions of the Atrina zelandica landscape on the macrofauna, variables were also calculated for a number of different sampling grains around each macrofaunal core. Grain sizes used were (Fig. 3): (1) the video quadrat from which a core was collected; (2) 3 contiguous quadrats centred around the core; (3) 5 contiguous quadrats centred around the core; (4) 7 contiguous quadrats centred around the core; and (5) 9 contiguous quadrats centred around the core. For the different grains used, the total density of $A$. zelandica and $A$. zelandica size were averaged over the quadrats.

Seven environmental variables were measured or estimated: percent volumes of medium sand, fine sand, silt and clay; percent weight of organic matter; site depth and current velocity. Samples of sediment for particle size analysis were digested in $6 \%$ hydrogen peroxide for $48 \mathrm{~h}$ to remove organic matter and dispersed using Calgon before being analysed by a Mastersizer laser system to produce percent volumes for the medium sand, fine sand, silt and clay fractions. Organic matter was measured by drying the sediment at $90^{\circ} \mathrm{C}$ for $48 \mathrm{~h}$, then combusting for $3 \mathrm{~h}$ at $550^{\circ} \mathrm{C}$. Depth data were collected at each site using a Raytheon depth sounder. Tidally-averaged, depthaveraged velocity for a spring tide was derived from a layered 3 dimensional hydrodynamic model of the harbour and the surrounding area (Oldman \& Black 1997). 
As the model did not cover all the sites outside the harbour, current velocities used for sites in Martins Bay (see Fig. 1) were only estimates, based on model results at the bays immediately outside the harbour.

Statistical analyses. As there were no significant differences in benthic community type or measures of the spatial distribution of Atrina zelandica between the 2 transects sampled at a site, results from each pair of transects were combined for the following analyses.

The techniques listed below in Steps 3 and 4 use partial regression analysis to explore the relationship between environmental variables, Atrina zelandica distributions and benthic macrofaunal communities. That is, effects of other factors are partialled out. For example, the relationship found between A. zelandica density and numbers of suspension feeders is that present when any relationship between numbers of suspension feeders and size, minimum distance and maximum distance is taken into account. While multiple regression is a powerful tool for exploring the importance of potentially covarying factors, highly correlated factors may still cause problems (usually revealed by a factor which drops in and out of importance or changes sign depending on the order in which other factors are included in the model). In our study, correlations between measures of the spatial distribution of $A$. zelandica were not high (total density of A. zelandica and minimum nearest-neighbour distance between $A$. zelandica, $\mathrm{r}^{2}=0.07$, total density of $A$. zelandica and maximum clear distance between individual $A$. zelandica, $\mathrm{r}^{2}=0.10$ and minimum nearest-neighbour and maximum clear distance between individual $A$. zelandica, $\left.\mathrm{r}^{2}=0.25\right)$. Even so, variables were removed or input in a number of different orders to ensure that this did not influence the outcome.

(1) Community descriptions. Similarities in mean community composition between sites were explored using correspondence analysis. This analysis was conducted on square-root-transformed data as this gave the greatest explanatory power in 2 dimensions. Taxa ordinations from the correspondence analysis and an analysis based on Bray-Curtis similarities (SIMPER, Clarke 1993) were used to determine taxa contributing to differences between sites.

(2) At what scale do Atrina zelandica most affect the benthic macrofauna? CCA (ter Braak 1986,1987) were carried out to relate the macrofauna found in the cores (response variables) to spatial arrangements of $A$. zelandica (explanatory variables). Separate analyses were performed for each different sampling grain. These analyses were carried out using the program CANOCO (ter Braak 1988,1990, ter Braak \& Smilauer 1998) with down-weighting of rare taxa and untransformed abundances as these options allowed the correspondence analysis to explain more of the variability than other options. The percent variability explained by the canonical correspondence analysis was determined by dividing the sum of all canonical eigenvalues by the overall sum of the eigenvalues from the correspondence analysis (ter Braak \& Verdonschot 1995). Comparisons of the percent variability explained at each grain were used to determine the effectiveness of the explanatory variables at each grain and the scale at which relationships were strongest.

(3) Which measurements representing the smallscale spatial arrangement of individual Atrina zelandica most affect the benthic macrofauna? CCA were carried out with important variables selected using forward selection; the overall model was tested for significance using the unrestricted permutation test available in the CANOCO programme. The model was also checked for dependence on the initial choice of variables selected by using a number of different starting variables. Unfortunately, backwards elimination, probably the more appropriate method for investigation of relationships, is not yet available in the programme CANOCO. As the estimates of the spatial arrangement of $A$. zelandica from the different grains were not independent of one another, we forced the selection of variables to include only 1 estimate of each $A$. zelandica spatial arrangement variable (i.e. size, total density, minimum distance and maximum distance).

We anticipated that the overall community response might be mixed depending on taxa feeding mode, mobility and depth at which they lived. Therefore, multi-regression analyses using benthic macrofaunal aggregate groups as dependent variables and the spatial arrangement of the Atrina zelandica were also run. Backwards elimination using a 0.15 exit probability level was used (SAS 1989).

(4) Do broad-scale environmental gradients affect relationships between the spatial arrangement of individual Atrina zelandica and the benthic macrofaunal community? In order to determine whether results were consistent between the different hydrodynamic and sediment regimes of the harbour and the coast, all following analyses were conducted on data from (1) all sites, (2) outside harbour sites only and (3) inside harbour sites only. Also, CCA were run on the macrofaunal data from the cores using both the $A$. zelandica data and the environmental data as explanatory variables.

\section{RESULTS}

\section{Site community and physical descriptions}

Correspondence analysis of the benthic macrofauna revealed a number of site groupings (Fig. 4). While outside harbour sites were distinctly different from 


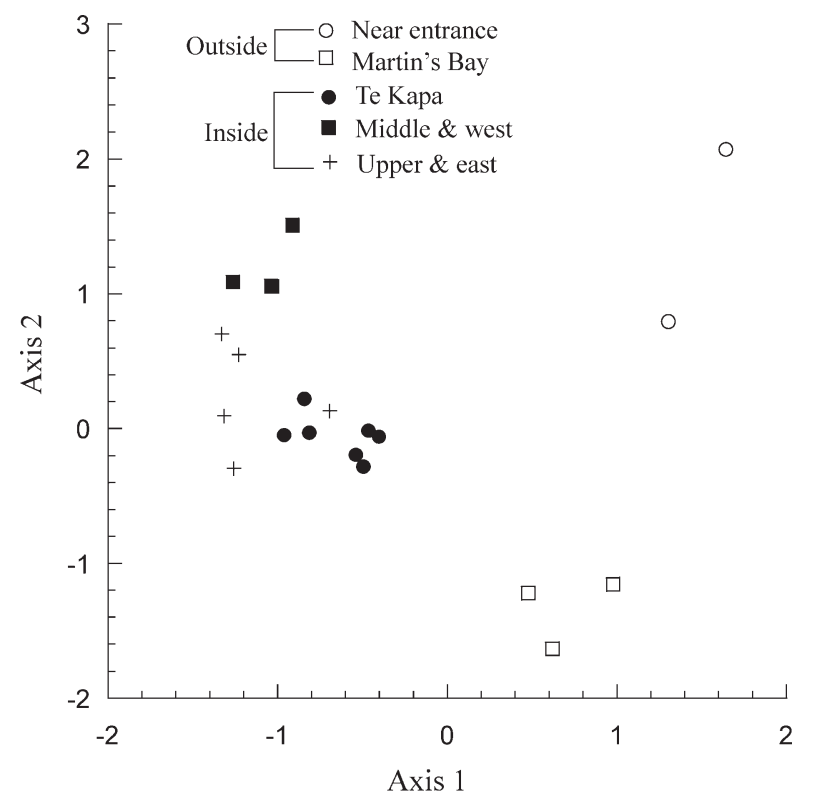

Fig. 4. Ordination plot of the first 2 axes derived from the correspondence analysis of the square-root-transformed sitemean data

inside sites, there were a number of smaller groupings. Sites outside the harbour near the mouth were different from sites in Martins Bay. Sites within the harbour could be divided into 3 main groups: sites near and within Te Kapa Inlet, sites in the middle of the main harbour on the westward side and those furthermost up the main harbour and on the eastern side. The exception to this was a site midway up the main harbour, which grouped with Te Kapa Inlet sites. Differences between groups were not driven by changes in the most abundant taxa; neither did they reflect changes at high-order taxonomic resolution (e.g. bivalves, polychaetes, echinoderms). Rather, differences were related to species changes at the family and genus level. For example, communities from Martins Bay sites were different to those from coastal sites nearer the harbour, having Scolecolepedes sp. (Polychaeta), Syllidae (Polychaeta), Paracolliopidae (Amphipoda), Halicarcinus tongi (Decapoda), Dosina zelandica (Bivalvia) and Cominella adspersa (Gastropoda). Generally, sites outside the harbour had higher total numbers of individuals and taxa than those inside the harbour (Table 1). Numbers of predators/ scavengers, surface dwellers and mobile organisms were proportionally higher outside the harbour and numbers of deposit feeders were proportionally higher inside.

The size range of Atrina zelandica was slightly larger outside the harbour, although densities tended to be lower (Table 1). There were also differences in the predominant spatial arrangement of Atrina found in the 2 areas. Inside the harbour, patches were often

Table 1. Atrina zelandica. Maximum and minimum data observed for macrofaunal aggregate groups, spatial arrangement and environmental variables inside and outside of the harbour

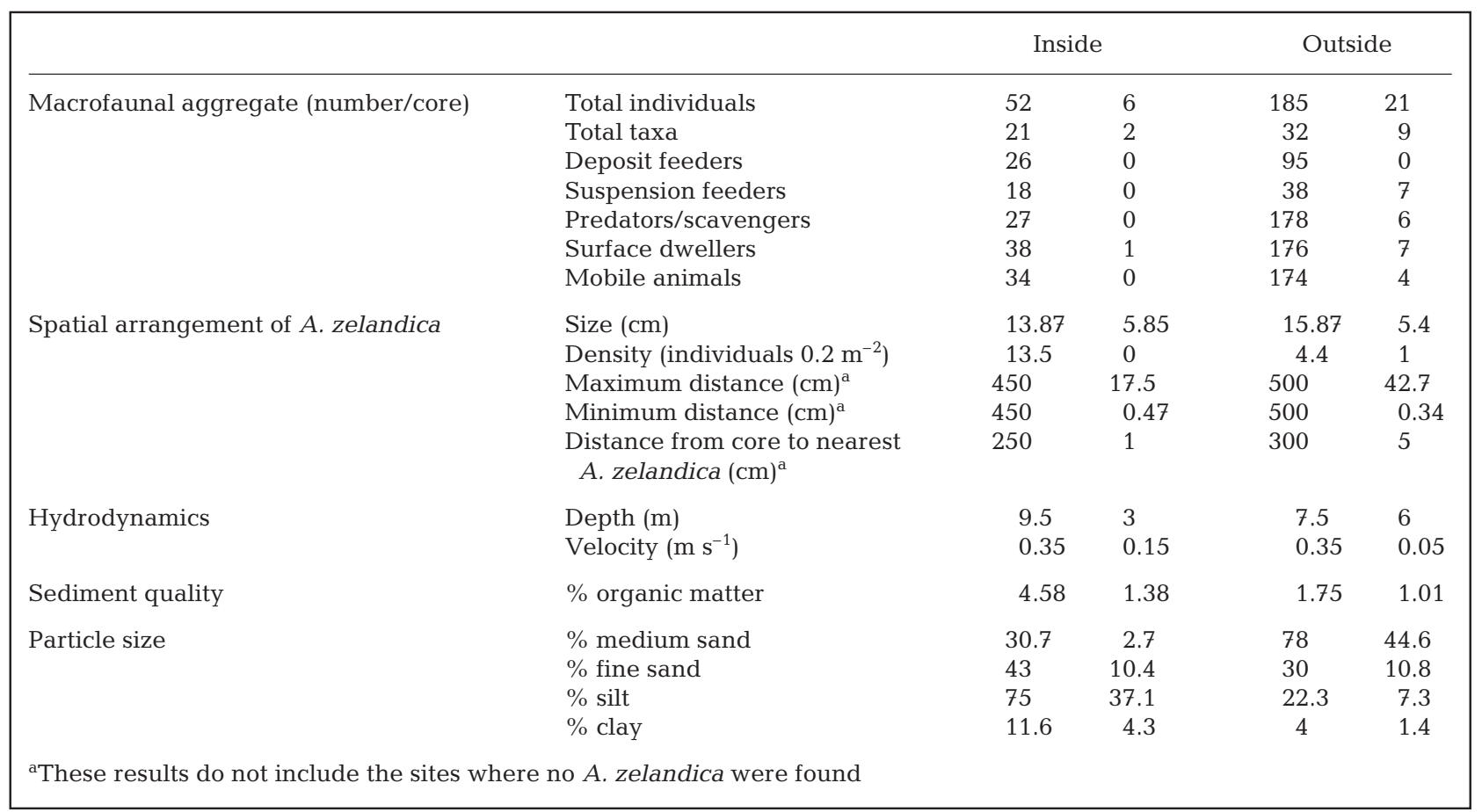


very dense, and small clusters ( $<0.5 \mathrm{~m}$ diam.) within larger patches $(\geq 10 \mathrm{~m})$ were often observed. Thus the minimum distance between A. zelandica was often very small (Table 1) and the maximum distance often represented the distance between the small clusters of A. zelandica. Outside the harbour, A. zelandica were more sparsely distributed. Single A. zelandica were common and patches (at the scale of a quadrat) often comprised of only 2 to 3 individuals. The minimum distance between $A$. zelandica was often $>0.5 \mathrm{~m}$ and was frequently equal to the maximum distance that could be determined from the videod transects.

Sites outside the harbour were also generally deeper and had coarser sediments with less organic matter (Table 1).

\section{At what scale do Atrina most affect the benthic macrofauna?}

Our results suggest that the effect of Atrina zelandica on benthic macrofaunal community composition is unlikely to be a localized effect occurring within a $0.5 \times$ $0.4 \mathrm{~m}$ area. We found a consistent increase in the effectiveness of the spatial arrangement of $A$. zelandica in explaining the benthic macrofaunal community over all sites, with increasing grain size (Table 2). The benthic macrofauna from a core was best related to measures of the spatial arrangement of $A$. zelandica calculated from the $4.5 \mathrm{~m}$ strip centred around the core. Separating inside from outside the harbour sites showed that measurements of $A$. zelandica made at the smallest grain were, again, least effective at explaining benthic macrofaunal community composition (Table 2). However, the continued increase in percent of variability in community composition explained with increasing grain found inside the harbour was not apparent outside the harbour. Only a low amount of variability was explained, especially inside the harbour and when all sites were considered together, but this is not unusual for multivariate analysis of ecological data (ter Braak \& Verdonschot 1995), particularly when small-scale sampling is involved. Even for univariate analyses, a change of $20 \%$ would be considered strong, with changes around $10 \%$ being considered weak (Hall et al. 1990). The maximum differences in percent of variability in community composition explained for all sites $(10.6 \%)$, inside harbour sites $(6.9 \%)$ or outside harbour sites $(21.4 \%)$ suggests important differ-
Table 2. Atrina zelandica. Results of CCA relating the macrofaunal data collected by the cores to the spatial arrangements found at different grains for all sites, inside harbour and outside harbour sites. Values given are \% explained (i.e. sum of the canonical eigenvalues $\times 100 /$ sum of all eigenvalues)

\begin{tabular}{|lccc|}
\hline Grain & $\begin{array}{c}\text { All } \\
\text { sites }\end{array}$ & $\begin{array}{c}\text { Inside } \\
\text { harbour } \\
\text { sites }\end{array}$ & $\begin{array}{c}\text { Outside } \\
\text { harbour } \\
\text { sites }\end{array}$ \\
\hline $0.4 \times 0.5 \mathrm{~m}$ & 5.0 & 5.5 & 12.1 \\
$0.4 \times 1.5 \mathrm{~m}$ & 9.2 & 6.1 & 19.8 \\
$0.4 \times 2.5 \mathrm{~m}$ & 9.5 & 6.7 & 21.3 \\
$0.4 \times 3.5 \mathrm{~m}$ & 10.1 & 6.9 & 19.5 \\
$0.4 \times 4.5 \mathrm{~m}$ & 10.6 & 6.9 & 21.4 \\
\hline
\end{tabular}

ences in the strength of processes and/or responses between the sites inside and outside the harbour.

\section{Which measurements representing the spatial arrangement of individual Atrina most affect the benthic macrofauna?}

Clear differences were found between the specific aspects of the spatial arrangement of Atrina zelandica influencing benthic macrofaunal communities and the grains at which they were operating (Table 3). Inside the harbour, variability explained was lowest and minimum distance between $A$. zelandica was not important. Also, the maximum distance was only important at the smallest grain, where it represents the distance between small clusters of $A$. zelandica occurring within larger patches/beds. Outside the harbour, over $20 \%$ of the variability was explained by our 4 mea-

Table 3. Atrina zelandica. Results of CCA relating the macrofauna collected by the cores to spatial arrangements found over all sites, and inside harbour and outside harbour sites; sum of all eigenvalues equals $7.880,6.251$ and 4.909 respectively. The longest linear dimension of grain at which each specific aspect of the spatial arrangement of A. zelandica was important is given in metres. Explanatory variables were selected by forward selection and the significance level explored by permutation tests. Max. = maximum distance between A. zelandica (normally between patches), min. = minimum nearestneighbour distance, density $=$ average total density of $A$. zelandica, size $=$ average width of $A$. zelandica

\begin{tabular}{|llll|}
\hline All sites & $\begin{array}{c}\text { Inside harbour } \\
\text { sites }\end{array}$ & $\begin{array}{c}\text { Outside harbour } \\
\text { sites }\end{array}$ \\
\hline Variables & Min. (1.5) & Density (4.5) & Size (4.5) \\
& $\begin{array}{l}\text { Max. (1.5) } \\
\text { Size (2.0) }\end{array}$ & $\begin{array}{l}\text { Max. (0.5) } \\
\text { Size (3.5) }\end{array}$ & $\begin{array}{l}\text { Min. (4.5) } \\
\text { Max. (2.5) } \\
\text { Density (3.5) }\end{array}$ \\
Significance & 0.01 & 0.032 & Density (3.5) \\
\% variance explained & 11.0 & 7.2 & 0.019 \\
\hline
\end{tabular}


Table 4. Atrina zelandica. Relationships found by multiple regression between number of individuals in macrofaunal aggregative variables and factors representing the spatial arrangement. Direction of the effect is given as ' + ' or ' - '. The longest linear dimension of grain (in $\mathrm{m}$ ) at which the effect was observed is given in brackets. $\mathrm{L}=$ natural logarithmic transformation, Max. $=$ maximum distance between $A$. zelandica (normally between $A$. zelandica patches), Min. = minimum nearest-neighbour distance, Density $=$ mean number of $A$. zelandica quadrat ${ }^{-1}$, Size $=$ average width of $A$. zelandica shell, Distance $=$ distance from core position to the nearest $A$. zelandica. Variables are given in order of decreasing $\mathrm{p}$-value

\begin{tabular}{|c|c|c|c|c|c|c|}
\hline & All & $\mathrm{R}^{2}$ & Inside harbour & $\mathrm{R}^{2}$ & Outside harbour & $\mathrm{R}^{2}$ \\
\hline Deposit feeders & $\begin{array}{l}\text { +Max. (0.5) } \\
\text { +Size (2.5) } \\
\text {-Density (4.5) }\end{array}$ & 0.15 & $\begin{array}{l}\text {-Distance } \\
\text {-Min. }(0.5) \\
\text {-Size }(1.5) \\
\text { +Max. }(0.5)\end{array}$ & 0.44 & $\begin{array}{l}\text { +L Density (4.5) } \\
\text { +Size (1.5) }\end{array}$ & 0.17 \\
\hline Suspension feeders & -Max. (4.5) & 0.10 & $\begin{array}{l}\text { +Density (0.5) } \\
\text {-Max. (3.5) } \\
\text { +Min. (2.5) }\end{array}$ & 0.10 & $\begin{array}{l}\text { +Min. (1.5) } \\
\text { +L Size (2.5) }\end{array}$ & 0.27 \\
\hline Predators/scavengers & $\begin{array}{l}\text { +L Min. (4.5) } \\
\text { +Max. (3.5) } \\
\text { +Size (1.5) }\end{array}$ & 0.17 & +Max. (1.5) & 0.11 & +Min. (4.5) & 0.29 \\
\hline Surface dwellers & $\begin{array}{l}\text { +Max. (2.5) } \\
\text { +Size (4.5) }\end{array}$ & 0.12 & $\begin{array}{l}\text { +Max. }(0.5) \\
\text {-L Min. (0.5) }\end{array}$ & 0.21 & $\begin{array}{l}\text { +Min. }(4.5) \\
\text {-L Density (0.5) } \\
\text { +L Size }(0.5)\end{array}$ & 0.45 \\
\hline Highly mobile & $\begin{array}{l}\text { +Distance } \\
\text { +Max. }(2.5) \\
\text { +Size }(4.5) \\
\text { +L Min. }(0.5)\end{array}$ & 0.16 & $\begin{array}{l}\text { +Max. (0.5) } \\
\text {-L Min. (0.5) }\end{array}$ & 0.25 & $\begin{array}{l}+ \text { Max. (4.5) } \\
\text {-Density (0.5) }\end{array}$ & 0.42 \\
\hline Total individuals & $\begin{array}{l}\text { +L Min. (4.5) } \\
\text { +Size (2.5) }\end{array}$ & 0.20 & + Max. (0.5) & 0.20 & +Max. (4.5) & 0.11 \\
\hline Total taxa & $\begin{array}{l}\text {-Density (3.5) } \\
\text { + Size (4.5) }\end{array}$ & 0.23 & $\begin{array}{l}\text { +Max. }(0.5) \\
\text {-L Density (0.5) }\end{array}$ & 0.13 & -L Max. (1.5) & 0.38 \\
\hline
\end{tabular}

sures of the spatial arrangement of Atrina. Maximum distance was important at a larger grain $(2.5 \mathrm{~m})$ though still at a lower grain than that of the other variables (Table 3). Average total density and size were important variables over all sites, at inside harbour sites and at outside harbour sites.

As expected, spatial arrangement of Atrina zelandica was also related to different aggregate groups in different ways and the percent of variability in community composition explained was greater than for the multivariate analyses, with 4 aggregate groups having around $40 \%$ variability explained by our 4 measures of the spatial arrangement of A. zelandica (Table 4). The amount of variability explained by the regression models was largest for sites outside the harbour for all but numbers of deposit feeders and total numbers of individuals. The different aggregate groups also responded differently inside and outside of the harbour. As a result, the regressions conducted over all sites only once explained the most variance. The number of deposit feeders, surface dwellers and highly mobile individuals, total number of individuals and total number of taxa inside the harbour were all related to the maximum distance at the smallest grain. Outside the harbour, maximum distance was again important but at a larger grain (4.5 $\mathrm{m}$ for total number of individuals and $1.5 \mathrm{~m}$ for total number of taxa). Inside the harbour, the total number of taxa was also affected by density of A. zelandica found in the $0.5 \mathrm{~m}$ directly around the core.

These analyses indicate that total density of Atrina zelandica alone is not a satisfactory explanatory variable. In fact, it is only an important factor inside the harbour for 2 groups (total number of taxa and number of suspension feeders) and outside the harbour for 3 groups (number of deposit feeders, surface dwellers and mobile macrofauna) (Table 4). Generally the most useful measurement of spatial arrangement is the maximum distance, which is generally the estimate of distance between patches along transects. This was important for all variables inside the harbour and for mobile macrofauna, total number of individuals and total number of taxa outside the harbour. The minimum distance between $A$. zelandica inside patches was also important and, again, more often inside the harbour than outside. Inside the harbour, 4 variables were influenced both by minimum distance and maximum distance. However, outside the harbour the important factor was either the minimum distance or maximum distance but never both. One of these factors 
Table 5. Results of CCA relating the macrofaunal community composition in each core to the environmental variables and the spatial arrangement from the core quadrat, for all sites, inside and outside harbour sites; sum of all eigenvalues equals 7.880,6.251 and 4.909, respectively. Variables are given in the order that the forward selection procedure brought them into the model. Atrina zelandica measurements are in bold and variables which may be influenced by $A$. zelandica are italicised. The longest linear dimension of grain in $\mathrm{m}$ is given in brackets

\begin{tabular}{|c|c|c|c|}
\hline & All sites & $\begin{array}{l}\text { Inside harbour } \\
\text { sites }\end{array}$ & $\begin{array}{c}\text { Outside harbour } \\
\text { sites }\end{array}$ \\
\hline Variables & $\begin{array}{l}\text { Medium sand } \\
\text { Velocity } \\
\text { Fine sand } \\
\text { Silt } \\
\text { Organic matter } \\
\text { Total (4.5) } \\
\text { Distance } \\
\text { Depth } \\
\text { Max. (1.5) } \\
\text { Min. (1.5) }\end{array}$ & $\begin{array}{l}\text { Silt } \\
\text { Total (4.5) } \\
\text { Fine sand } \\
\text { Velocity } \\
\text { Clay } \\
\text { Min. (3.5) }\end{array}$ & $\begin{array}{l}\text { Organic matter } \\
\text { Velocity } \\
\text { Silt } \\
\text { Min. (4.5) } \\
\text { Medium sand } \\
\text { Size (1.5) }\end{array}$ \\
\hline Significance & 0.001 & 0.010 & 0.021 \\
\hline$\%$ variance explained & 20.0 & 11.1 & 36.6 \\
\hline
\end{tabular}

\section{DISCUSSION}

In this study we have described a multiresolution-sampling strategy analysed by regression-based models. With this technique, we were able to determine that correlations between macrofauna and Atrina zelandica varied with scale and broad environmental characteristics. A. zelandica remained an important predictor of macrofaunal community, even when the effect of the broad-scale environmental factors were removed. A. zelandica appeared to create a landscape mosaic, with macrofauna related to the spatial arrangement of $A$. zelandica, rather than just $A$. zelandica density. This, along with some of our other results (Table 6, Fig. 5), suggests that generalising from manipulative experiments can be problematic. However, as our results confirm and explain those found in a manipulative experiment conducted concurrently in the same area (Cummings et al. 2001), companion studies involving both surveys and experiments may be an integral part of achieving realistic generalisations.

\section{Multi-resolution sampling and regression based models}

Our results emphasise the value of utilising regression-based models within a multi-resolution sampling design when investigating multi-scale species interactions. Regression-based models allow us to treat much of the variability in the data as information, and are quick and easy to use. In fact, most of the effort in this study

\section{Do broad-scale environmental gradients affect relationships between the spatial arrangement of individual Atrina and the benthic macrofaunal community?}

Variables influencing the benthic macrofaunal community composition were relatively consistent (Table 5), with current velocity and sediment percentage silt content being important over all sites and for sites inside and outside the harbour. However, inclusion of physical variables did not eliminate the importance of the spatial arrangement of Atrina zelandica to the benthic macrofauna, as the minimum distance between $A$. zelandica was also important over all sites and for sites inside and outside the harbour. The remaining variables important inside the harbour did not feature outside the harbour and vice-versa (Table 5). The percent variability explained was considerably greater outside the harbour (36\%) than inside $(11 \%)$.

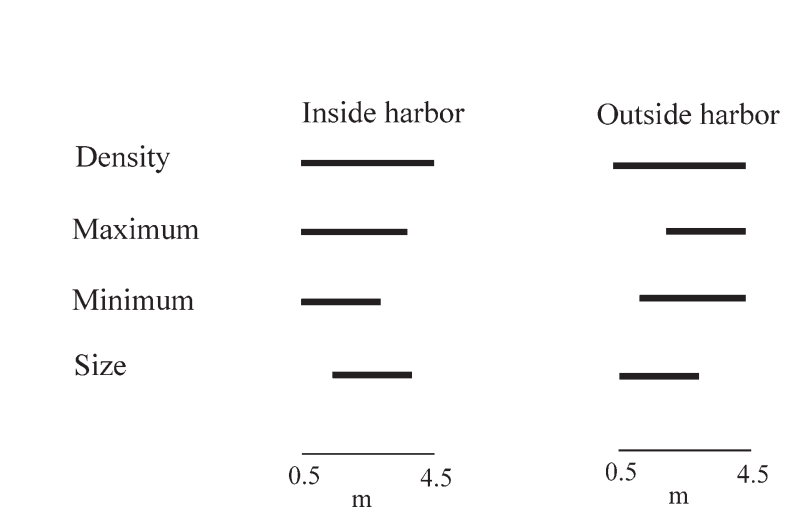

Fig. 5. Atrina zelandica. The grains (covered by this study) at which different aspects of the spatial arrangement were related to benthic macrofauna. Maximum = maximum distance between $A$. zelandica, Minimum $=$ minimum nearest neighbour distance, Density $=$ mean number of $A$. zelandica per quadrat, Size = average width of $A$. zelandica shell 
Table 6. Summary of findings and their potential importance to generalities involving interspecific interactions and to the design and interpretation of manipulative experiments

\begin{tabular}{|lll|}
\hline \multicolumn{1}{|c}{ Our findings } & \multicolumn{1}{c}{ Generalities } & \multicolumn{1}{c}{$\begin{array}{c}\text { Implications for manipulative } \\
\text { experiments }\end{array}$} \\
\hline $\begin{array}{l}\text { Benthic macrofauna were related to } \\
\text { the spatial distribution of Atrina }\end{array}$ & $\begin{array}{l}\text { Density of species is not necessarily } \\
\text { the major factor affecting interac- } \\
\text { tions }\end{array}$ & $\begin{array}{l}\text { The spatial distribution of a species } \\
\text { may be important in determining } \\
\text { outcomes }\end{array}$ \\
$\begin{array}{l}\text { Which aspect of the spatial distribu- } \\
\text { tion of Atrina was most important } \\
\text { was affected by broad-scale }\end{array}$ & $\begin{array}{l}\text { Broad-scale physical variables and } \\
\text { local species pools can play an } \\
\text { faunal species }\end{array}$ & $\begin{array}{l}\text { Consistent responses between areas } \\
\text { with differing physical properties } \\
\text { and species are unlikely }\end{array}$ \\
$\begin{array}{l}\text { The relationship between Atrina } \\
\text { and macrofaunal community was } \\
\text { strongest at scales over } 2 \text { m }\end{array}$ & $\begin{array}{l}\text { Differences in the scale at which an } \\
\text { interaction changes strength may be } \\
\text { small and non-linear }\end{array}$ & $\begin{array}{l}\text { Interactions may be strongest at } \\
\text { scales larger than the normal size of } \\
\text { experiments and inconsistent } \\
\text { outcomes to experiments carried out } \\
\text { at varying scales are likely }\end{array}$ \\
$\begin{array}{l}\text { Different aspects of the spatial } \\
\text { distribution of } \text { Atrina were impor- } \\
\text { tant at different spatial scales }\end{array}$ & $\begin{array}{l}\text { The strength of relationships at } \\
\text { different scales can be used to } \\
\text { strengthen theories about underly- } \\
\text { ing mechanisms }\end{array}$ & $\begin{array}{l}\text { The natural range of spatial distribu- } \\
\text { tions and the variables that are most } \\
\text { important should be investigated } \\
\text { prior to experimentation }\end{array}$ \\
\hline
\end{tabular}

was in data collection. Using the regression models, we were able to determine the particular aspects of the small-scale spatial arrangement of Atrina zelandica which best explained the variability in benthic macrofauna. Placing finer-resolution sampling within measures of broad-scale characteristics (see Wiens 1989, Dayton 1994, Hewitt et al. 1998, Lobo et al. 1998) allowed us to optimise our sampling with respect to the heterogeneity of our explanatory variables, thus strengthening the observed response. Incorporating the broad-scale environmental variables in our community analyses also increased our explanatory power. Thrush et al. $(2000,2001)$ also found broad-scale gradients useful when analysing for differences in interspecific interactions (although see Dayton 1971, Menge 1976, Keddy 1991, Gurevitch \& Hedges 1993 for general examples of utilising environmental gradients).

Nevertheless, the analytical methods used have some weaknesses. Many of the relationships identified by canonical correspondence and multiple regression were weak, although Hall et al. (1990) suggested that percents explained as low as $10 \%$ can still be ecologically meaningful. Cohen (1988) suggests even lower $\mathrm{r}^{2}$ values may still signify weak effects in behavioural sciences, and ter Braak \& Verdonschot (1995) state that explaining only a low amount of variability in ordinations is not unusual for ecological data. The low percent variability that can be explained in the first 4 axes of the correspondence analysis limited the percent variability explainable by the independent variables. This problem was not unique to correspondence analy- sis, as use of MDS also resulted in unsatisfactory stress values. In the regressions, at least some of the weaknesses of the relationships were due to factor ceiling responses, i.e. correlations between variables that appear random except for a lack of points above or below a certain line (Thomsen et al. 1996). Factor ceilings occur in our data, at least at the aggregate group level. We attempted to overcome this by subdividing data based on criteria reflecting potential causes of differing responses to the independent variables, i.e. inside and outside the harbour data. This provided some useful insights and improved the percent variability explained, at least for outside the harbour sites. Further attempts could have been made on the basis of other broad-scale processes operating within the harbour, if classes could have been found containing enough data for analysis. However, the sampling intensity in our survey was low, as we tried to maximise the extent and resolution of the survey with the collection of a minimum number of core samples. A method that would allow us to more precisely determine the number of samples needed at a lower resolution from variability at a higher resolution would reduce the possibility of too few samples compromising study findings.

\section{Species interactions: Atrina and benthic macrofauna}

Marine soft-sediment studies investigating interspecific relationships often focus on density effects (see 
Olafsson et al. 1994 for a review, also more recently Thrush et al. 1996a,1997, Whitlatch et al. 1997, Alfaro \& Carpenter 1999, Botto \& Iribarne 1999, Crooks \& Khim 1999, Manderson et al. 1999). Even where natural variability in cover is included in the experimental design (e.g. Ragnarsson \& Raffaelli 1999), analysis is usually restricted to density comparisons. However, while our study found density useful, it was not the best explanatory variable for the effect of Atrina zelandica on benthic macrofauna. Generally, the most useful variable was either the minimum distance between individual $A$. zelandica or the maximum clear distance, the latter representing both the distance between small-scale clusters of $A$. zelandica within high density beds and the distance between individual $A$. zelandica in sparse beds. This suggests that $A$. zelandica may be as important in creating a habitat as in directly interacting with other species. Thus, we should consider organism interactions on the basis of dynamics within landscapes (such as is frequently done for habitat-organism interactions, e.g. McIntyre \& Wiens 2000 and Bowers \& Dooley 1999 amongst others) rather than just density-to-density comparisons (Table 6). This makes designing manipulative experiments more complex and suggests that before conducting manipulative experiments, a survey of natural communities is required to determine the range of spatial distributions available and the variables that are most important (e.g. Bowers \& Dooley 1999).

The lack of consistency found in the strength of relationships between inside and outside the harbour was anticipated and indicated that relationships between Atrina zelandica and benthic macrofauna are influenced by the interaction of a number of broad-scale factors. Firstly, our study encompassed a broad range of differences in the spatial arrangement of A. zelandica. Secondly, flow dynamics inside the harbour (driven by tidal currents) and on the coast (driven by waves) should interact differently with the $A$. zeland$i c a$, potentially affecting distribution of recruits and biodeposits into the beds. Thirdly, decreased sediment particle size and higher amounts of organic matter present inside the harbour could decrease the role of A. zelandica biodeposition on food resource patchiness, particularly if threshold effects and ratios of pseudofaeces to faeces production are important (Whitlatch 1980, Herman et al. 1999). Norkko et al. (2001) found higher biodeposition (and consequently higher organic carbon and nitrogen fluxes to the seafloor) near A. zelandica in Martins Bay than in Mahurangi Harbour, although sediment concentrations of organic carbon and nitrogen were higher in the harbour. Fourthly, our study area could be split into a number of regions based on benthic macrofaunal community composition, with more regions found within the harbour. Thus, the responses of benthic macrofauna to $A$. zelandica observed within each area were constrained by the taxa available and more variability in response was observed inside the harbour. A highly regionalised response of benthic macrofauna to $A$. zelandica was also observed in the companion A. zelandica-density-manipulation experiment carried out in areas of Mahurangi Harbour and Martins Bay (Cummings et al. 2001), implying that interactions between A. zelandica and benthic macrofauna were mediated through local species pools. The results found by Cummings et al. (2001) and Norkko et al. (2001) suggest that inside-harbour relationships are unlikely to be weaker than outside due to increased variability as a result of increased sample size.

Atrina zelandica remained an important predictor of macrofaunal community, even when the effect of the broad-scale environmental factors were removed. This, together with the general agreement of results between this survey and Cummings et al. (2001), and the provision of a mechanism for $A$. zelandica to influence macrofauna by Norkko et al. (2001), suggests that it is unlikely that the observed relationships between the 2 are due to some unmeasured environmental factor.

Defining the strength of relationships between the spatial distribution of the key species and associated benthic macrofauna over different scales enables us to match patterns with processes more clearly, thus providing stronger clues to underlying mechanisms. These can be related to the stronger but more spatial and temporally constrained inference that can be derived from manipulative field experiments. Information on the scale at which particular processes are operating can be gathered from the grain at which linkages between resolutions are most important. For example, inside the harbour, numbers of deposit feeders, surface dwellers and mobile animals are best related to both maximum and minimum distance at the smallest grain. As both of these variables probably represent measures of free space and quantity of biodeposits, it seems likely that, as suggested by Norrko et al. (2001), small-scale patchiness of A. zelandica affects individual living space and food resources available to these animals.

Most importantly, comparing model results across scales allowed us to determine the scales where the interspecific interactions were strongest. Our study suggests that the effect of Atrina zelandica on benthic macrofaunal communities is weakest at our smallest sampling scale (i.e. $40 \times 50 \mathrm{~cm}$ around the core). Thus, the effect of $A$. zelandica on benthic macrofaunal community composition is not simply a small-scale, local effect. The stronger links between A. zelandica and macrofauna found at larger spatial grains suggest that benthic macrofaunal communities respond to particu- 
lar-sized A. zelandica patches, highlighting the potential for cumulative (e.g. biodeposition, food and recruitment depletion or restricted movement) or hydrodynamic influences. Interestingly, differences were found between the spatial scale at which functional and community level responses to $A$. zelandica were strongest. For example, the spatial scale at which relationships between $A$. zelandica density and benthic macrofaunal communities were strongest was greater than $2 \mathrm{~m}$. However, some macrofaunal functional groups (i.e. numbers of suspension feeders from sites inside the harbour and numbers of mobile taxa from sites outside the harbour) were best related to density at a grain of $0.5 \mathrm{~m}$. While more consistency in results may be expected when studies focus on the interaction between a few selected species, at the community level a variety of organisms with different functional, mobility and trophic attributes are to be expected.

\section{Generalising from studies}

Similar to the companion study, a multi-site-time manipulative field experiment (Cummings et al. 2001), our survey does not indicate a simple relationship between Atrina zelandica and associated benthic macrofauna. This gives us confidence that the variability in response apparent in the manipulative experiment is not a scale artefact. Thrush et al. (2001) uses metaanalysis of the experiment and survey to link the results of both studies and generalise the mechanistic processes. However, specific survey findings relating spatial scale to strength of $A$. zelandica-benthic macrofauna relationships have important consequences for experimental design (Table 6). Firstly, the spatial scale at which the relationship between $A$. zelandica and the benthic macrofaunal community was strongest was greater than $2 \mathrm{~m}$. This limits the value of experiments, conducted on this species, with small plot sizes $(<2 \mathrm{~m})$. The number of experiments on species interactions with suspension feeders that produce inconclusive results (see Olafsson et al. 1994, Whitlatch et al. 1997) may indicate that this is a general problem. Secondly, our results support those of a number of studies that have demonstrated that the grain of sampling is important in determining results (e.g. Grassle et al. 1975, Jumars 1975, Smith \& Brumsickle 1989, Thrush et al. 1996b). The concept of grain should, therefore, be utilised when designing studies on landscape effects and patch dynamics.

Our results confirm that Atrina zelandica are most likely to affect benthic macrofauna through processes operating on a number of spatial scales rather than by processes all being most important at 1 scale (Table 6). Any manipulative experiment studying such interac- tions faces the problem of choosing which of many scales to manipulate. There are a variety of ways to help address this problem; for example, the use of meta-analysis to determine whether broad-scale processes affect the strength of relationships (Thrush et al. 2000); manipulating elements of scale in the experiment (e.g. Thrush et al. 1996b, Whitlatch et al. 1997); or determining scales of patchiness in cryptic fauna (Hewitt et al.1997) and conducting experiments within this heterogeneity (Thrush et al. 1997). In this study we designed a multi-resolution sampling strategy, based on large, visible epifauna, to survey effects on a number of scales. Survey approaches are often criticised for containing a large number of uncontrolled factors that confound interpretation and for difficulties in isolating cause-effect mechanisms. Conversely, experimental manipulations can be an overly simplistic treatment of naturally complex systems. Conducting both manipulative experiments on isolated mechanisms and surveys over a variety of environmental conditions and scales may be more useful than creating a dichotomy between detailed mechanistic understanding and generality.

In summary, we have shown the usefulness of multiscale statistical modelling when studying interspecific interactions, in particular for determining the spatial scales where interactions are greatest. Our results suggest that differences in the scale at which an interaction changes strength may be small and non-linear, making inconsistent outcomes to experiments carried out at varying scales likely. We also found that density of species is not necessarily the major factor affecting interspecific interactions; the spatial distribution of a species may be important in determining outcomes. This suggests that ecologists studying organism interactions should be more prepared to interpret results on the basis of patch dynamics within landscapes rather than as density-to-density comparisons. Furthermore, our work suggests that broad-scale physical variables and local species pools can play an important role in mediating outcomes of interspecific interactions, such that consistent responses between areas with differing physical properties are unlikely.

Acknowledgements. We would like to thank Bob Whitlatch and Rod Budd for their help with the fieldwork and Greig Funnell and Stephanie Turner for their help in identifying macrofauna. Bob Whitlatch also reviewed the manuscript. This research was funded by the New Zealand Foundation for Research Science and Technology (Co1X0007).

\section{LITERATURE CITED}

Alfaro AC, Carpenter RC (1999) Physical and biological properties influencing zonation patterns of a subtidal population of the marine snail, Astraea (Lithopoma) undosa Wood 1828. J Exp Mar Biol Ecol 240:259-283 
Andre C, Jonsson PR, Lindegarth M (1993) Predation on settling bivalves by benthic suspension feeders: the role of hydrodynamics and behaviour. Mar Ecol Prog Ser 97: 183-192

Azovsky AI, Chertoprood MV, Kucheruck NV, Rybnikov PV, Sapozhnikov FV (2000) Fractal properties of spatial distribution of intertidal benthic communities. Mar Biol 136: $581-590$

Bell SS, Hall MO, Robbins BD (1995) Towards a landscape approach in seagrass beds: using macroalgae accumulation to address questions of scale. Oecologia 104: 163-168

Bellehumeur C, Legendre P (1998) Multiscale sources of variation in ecological variables: modelling spatial dispersal, elaborating sampling designs. Landsc Ecol 13:15-25

Bergin TM, Best LB, Freemark KE, Koehler KJ (2000) Effects of landscape structure on nest predation in roadsides of a Midwestern agroecosystem: a multiscale analysis. Landsc Ecol 15:131-143

Botto F, Iribarne O (1999) Effects of the burrowing crab Chasmagnathus granulata (Dana) on the benthic community of a SW Atlantic coastal lagoon. J Exp Mar Biol Ecol 241: 263-284

Bowers MA, Dooley JJR (1999) A controlled, hierachical study of habitat fragmentation: responses at the individual, patch and landscape scale. Landsc Ecol 14:381-389

Clarke KR (1993) Non-parametric multivariate analyses of changes in community structure. Aust J Ecol 18:117-143

Cohen J (1988) Statistical power analysis for behavioural sciences. Hove \& London, Hillsdale, NJ

Commito JA (1987) Adult-larval interactions: predictions, mussels and cocoons. Estuar Coast Shelf Sci 25:599-606

Commito JA, Boncavage EM (1989) Suspension-feeders and coexisting infauna: an enhancement counterexample. J Exp Mar Biol Ecol 125:33-42

Crooks JA, Khim HS (1999) Architectural vs biological effects of a habitat-altering exotic mussel, Musculista senhousia. J Exp Mar Biol Ecol 240:53-75

Crowder LB, Cooper WE (1982) Habitat structural complexity and the interaction between bluegills and their prey. Ecology 63:1802-1813

Cummings VJ, Thrush SF, Hewitt JE, Turner SJ (1998) The influence of the pinnid bivalve Atrina zelandica (Gray) on benthic macroinvertebrate communities in soft-sediment habitats. J Exp Mar Biol Ecol 228:227-240

Cummings VJ, Thrush SF, Hewitt JE, Funnell GA (2001) The variable effect of a large suspension-feeding bivalve on infauna: experimenting in a complex system. Mar Ecol Prog Ser 209:159-175

Dayton PK (1971) Competition, disturbance and community organisation: the provision and subsequent utilization of space in a rocky intertidal community. Ecol Monogr 41: 351-389

Dayton PK (1972) Toward an understanding of community resilience and the potential effects of enrichment to the benthos at McMurdo Sound, Antarctica. In: Parker BC (ed) Proc Coll Conservation Problems in Antarctica. Allen Press, Lawrence, KS, p 81-95

Dayton PK (1994) Community landscape: scale and stability in hard bottom marine communities. In: Hildrew AG, Giller PS, Raffaelli D (eds) Aquatic ecology: scale, pattern and processes. Blackwell Scientific, Oxford, p 289-332

Dayton PK, Tegner MJ (1984) The importance of scale in community ecology: a kelp forest example with terrestrial analogs. In: Price PW, Slobodchikoff CN, Gaud WS (eds) A new ecology: novel approaches to interactive systems. John Wiley \& Sons, New York, p 457-483
Dayton PK, Tegner MJ, Edwards PB, Riser KL (1999) Temporal and spatial scales of kelp demography: the role of oceanographic climate. Ecol Monogr 69:219-250

Ertman SC, Jumars PA (1988) Effects of bivalve siphonal currents on the settlement of inert particles and larvae. J Mar Res 46:797-813

Fortin MJ, Drapeau P, Legendre P (1989) Spatial autocorrelation and sampling design in plant ecology. Vegetatio 83: 209-222

Giller PS, Hildrew AG, Raffaelli D (1994) Aquatic ecology: scale, pattern and process. Blackwell Scientific, Oxford

Grassle JF, Sanders HL, Hessler RR, Rowe GT, McLellan T (1975) Pattern and zonation: a study of the bathyal megafauna using the research submersible Alvin. Deep-Sea Res 22:457-481

Green MO, Hewitt JE, Thrush SF (1998) Seabed drag coefficient over natural beds of horse mussels (Atrina zelandica). J Mar Res 56:613-637

Gurevitch J, Hedges LV (1993) Meta-analysis: combining the results of independent experiments. In: Scheiner SM, Gurevitch J (eds) Design and analysis of ecological experiments. Chapman \& Hall, New York, p 378-398

Hall SJ, Raffaelli D, Turrell WR (1990) Predator-caging experiments in marine systems: a reexamination of their value. Am Nat 136:657-672

Herman PMJ, Middelburg JJ, VandeKoppel J, Heip CHR (1999) Ecology of estuarine macrobenthos. Adv Ecol Res 29:195-231

Hewitt JE, Legendre P, McArdle BH, Thrush SF, Bellhumeur C, Lawrie SM (1997) Identifying relationships between adult and juvenile bivalves at different spatial scales. J Exp Mar Biol Ecol 216:77-98

Hewitt JE, Thrush SF, Cummings VJ, Turner SJ (1998) The effect of changing sampling scales on our ability to detect effects of large-scale processes on communities. J Exp Mar Biol Ecol 227:251-264

Horne JK, Schneider DC (1994) Lack of spatial coherence of predators with prey: a bioenergetic explanation for Atlantic cod feeding on capelin. J Fish Biol 45:191-207

Jones CG, Lawton JH, Shachak M (1994) Organisms as ecosystem engineers. Oikos 69:373-386

Jumars PA (1975) Environmental grain and polychaete species' diversity in a bathyal benthic community. Mar Biol 34:253-266

Keddy PA (1991) Working with heterogeneity: an operators's guide to environmental gradients. In: Kolasa J, Pickett STA (eds) Ecological heterogeneity. Springer-Verlag, New York, p 181-201

King AW (1991) Translating models across scales in the landscape. In: Turner MG, Gardner RH (eds) Quantative methods in landscape ecology. Springer-Verlag, New York, p 479-518

Lawton JH, Jones CG (1995) Linking species and ecosystems: organisms as ecosystem engineers. In: Jones CG, Lawton $\mathrm{JH}$ (eds) Linking species and ecosystems. Chapman \& Hall, New York, p 141-150

Lee SY, Kneib RT (1994) Effects of biogenic structure on prey consumption by the xanthid crabs Eurytium limosum and Panopeus herbstii in a salt marsh. Mar Ecol Prog Ser 104: $39-47$

Legendre P, Legendre L (1998) Numerical ecology. Elsevier Science BV, Amsterdam

Lobo AL, Moloney K, Chic O, Chiariello N (1998) Analysis of fine-scale spatial pattern of a grassland from remotelysensed imagery and field collected data. Landsc Ecol 13: 111-131

Luckenbach MW (1984) Settlement and early post-settlement 
survival in the recruitment of Mulinia lateralis (Bivalvia). Mar Ecol Prog Ser 17:245-250

Manderson JP, Phelan BA, Bejda AJ, Stehlik LL, Stoner AW (1999) Predation by striped searobin (Prionotus evolans, Triglidae) on young-of-the-ear winter flounder (Pseudopleuronectes americanus, Walbaum): examining prey size selection and prey choice using field observations and laboratory experiments. J Exp Mar Biol Ecol 242:211-231

McIntyre NE, Wiens JA (2000) A novel use of the lacunarity index to discern landscape function. Landsc Ecol 15: $313-321$

Menge BA (1976) Relative importance of recruitment and other causes of variation on rocky intertidal community structure. J Exp Mar Biol Ecol 146:69-100

Moody A, Woodcock CE (1995) The influence of scale and the spatial characteristics of landscapes on land-cover mapping using remote sensing. Landsc Ecol 10:363-379

Norkko A, Hewitt JE, Thrush SF, Funnell GA (2001) Benthic pelagic coupling and suspension-feeding bivalves: linking site-specific sediment flux and biodeposition to benthic community structure. Limnol Oceanogr 46:2067-2072

Olafsson EB, Peterson CH, Ambrose WG (1994) Does recruitment limitation structure populations and communities of macro-invertebrates in marine soft sediments: the relative significance of pre- and post-settlement processes. Oceanogr Mar Biol Annu Res 32:65-109

Oldman JW, Black KP (1997) Mahurangi Estuary numerical modelling. National Institute of Water and Atmospheric Research, Hamilton, New Zealand

Ragnarsson SA, Raffaelli D (1999) Effects of the mussel Mytilus edulis L. on the invertebrate fauna of sediments. J Exp Mar Biol Ecol 241:31-43

SAS (1989) SAS/STAT Users guide. SAS Institute, Cary, NC

Schneider DC (1994) Quantitative ecology: spatial and temporal scaling. Academic Press, San Diego, CA

Schneider DC, Walters R, Thrush SF, Dayton PK (1997) Scaleup of ecological experiments: density variation in the mobile bivalve Macomona liliana. J Exp Mar Biol Ecol 216: $129-152$

Smith CR, Brumsickle SJ (1989) The effect of patch size and substrate isolation on colonization modes and rate in an intertidal sediment. Limnol Oceanogr 34:1263-1277

ter Braak CJF (1986) Canonical correspondence analysis: a new eigenvector technique for multivariate direct gradient analysis. Ecology 67:1167-1179

ter Braak CJF (1987) The analysis of vegetation-environment relationships by canonical correspondence analysis. Vegetatio 69:69-77

ter Braak CJF (1988) CANOCO—a FORTRAN program for canonical community ordination by partial detrended canonical correspondence analysis and redundancy analysis. Agricultural Mathematics Group, Wageningen

ter Braak CJF (1990) Update notes: CANOCO version 3.10. Agricultural Mathematics Group, Wageningen

ter Braak CJF, Smilauer P (1998) CANOCO release 4 reference manual and user's guide to Canoco for Windowssoftware for canonocal community ordination. Microcomputer Power, Ithaca, NY

ter Braak CJF, Verdonschot PFM (1995) Canonical correspon-

Editorial responsibility: Otto Kinne (Editor),

Oldendorf/Luhe, Germany

dence analysis and related multivariate methods in aquatic ecology. Aquat Sci 57:153-187

Thomsen JD, Weiblen G, Thomson BA, Alfaro S, Legendre P (1996) Untangling multiple factors in spatial distributions: lilies, gophers and rocks. Ecology 77:1698-1715

Thrush SF (1991) Spatial patterns in soft-bottom communities. TREE 6:75-79

Thrush SF, Hewitt JE, Pridmore RD, Cummings VJ (1996a) Adult/juvenile interactions of infaunal bivalves: contrasting outcomes in different habitats. Mar Ecol Prog Ser 132: 83-92

Thrush SF, Whitlatch RB, Pridmore RD, Hewitt JE, Cummings VJ, Maskery M (1996b) Scale dependent recolonization: the role of sediment stability in a dynamic sandflat habitat. Ecology 77:2472-2487

Thrush SF, Schneider DC, Legendre P, Whitlatch RB and 9 others (1997) Scaling-up from experiments to complex ecological systems: where to next? J Exp Mar Biol Ecol 216:243-254

Thrush SF, Lawrie SM, Hewitt JE, Cummings VJ (1999) The problem of scale: uncertainties and implications for softbottom marine communities and the assessment of human impacts. In: Gray TS, Ambrose W Jr, Szaniawska A (eds) Marine biogeochemistry, NATO Advanced Research Workshop. Kluwer, Dordrecht, p 195-210

Thrush SF, Hewitt JE, Cummings VJ, Green MO, Funnell GA, Wilkinson MR (2000) Improving the generality of field experiments: the interaction of processes operating over different spatial scales on intertidal sandflats. Ecology 81: 399-415

Thrush SF, Cummings VJ, Hewitt JE, Funnell GA, Green MO (2001) The role of suspension feeding bivalves in influencing macrofauna: variations in response. University Press of South Carolina, Columbia, SC, p 87-100

Warwick RM, McEvoy AJ, Thrush SF (1997) The influence of Atrina zelandica Gray on nematode diversity and community structure. J Exp Mar Biol Ecol 214:231-247

Whitlatch RB (1980) Patterns of resource utilization and coexistence in marine intertidal deposit-feeding communities. J Mar Res 38:743-765

Whitlatch RB, Hines AH, Thrush SF, Hewitt JE, Cummings VJ (1997) Benthic faunal responses to variations in patch density and patch size of a suspension-feeding bivalve inhabiting a New Zealand intertidal sandflat. J Exp Mar Biol Ecol 216:171-190

Whitlatch RB, Lohrer AM, Thrush SF, Prodmore SF, Hewitt JE, Cummings VJ, Zajac RN (1998) Scale-dependent benthic recolonization dynamics: life stage-based dispersal and demographic consequences. Hydrobiologia 375/376: $217-226$

Wiens JA (1986) Spatial scale and temporal variation in studies of shrubsteppe birds. In: Diamond J, Case TJ (eds) Community ecology. Harper \& Row, New York, p 154-172

Wiens JA (1989) Spatial scaling in ecology. Funct Ecol 3: 385-397

Wiens JA, Stenseth NC, Van Horne B, Ims RA (1993) Ecological mechanisms and landscape ecology. Oikos 66:369-380

Woodin SA (1976) Adult-larval interactions in dense faunal assemblages: patterns of abundance. J Mar Res 34:25-41

Submitted: October 1, 2001; Accepted: April 23, 2002

Proofs received from author(s): August 6, 2002 